\title{
Enzymatic Disruption of Biofilms During Cheese Manufacturing: A Mini Review
}

\author{
Murali Kumar $^{1 *}$, Joseph Tierney ${ }^{2}$ and Martin Wilkinson ${ }^{1}$ \\ ${ }^{1}$ Department of Biological Sciences, University of Limerick, Limerick, Ireland, ${ }^{2}$ Glanbia Ingredients, Kilkenny, Ireland
}

\section{OPEN ACCESS}

Edited by:

Giacomo Zara

University of Sassari, Italy

Reviewed by:

Efstathios D. Giaouris,

University of the Aegean, Greece

*Correspondence:

Murali Kumar

Murali.Kumar@ul.ie

Specialty section:

This article was submitted to

Food Microbiology,

a section of the journal

Frontiers in Microbiology

Received: 07 October 2021 Accepted: 18 November 2021 Published: 16 December 2021

Citation:

Kumar M, Tierney $\mathrm{J}$ and Wilkinson M (2021) Enzymatic Disruption of Biofilms During Cheese

Manufacturing: A Mini Review.

Front. Microbiol. 12:791061. doi: 10.3389/fmicb.2021.791061
Bacteria are capable of colonizing industrial processing surfaces creating biofilms on them which may adversely affect the quality and safety of products. Traditional cleaningin-place (CIP) treatments using caustic and nitric acid solutions have been known to exhibit variable efficiency in eliminating biofilm bacteria. Here, we introduce enzymes as an alternative to traditional CIP treatments and discuss their mechanism of action against bacterial biofilms in cheese manufacturing. In addition, we discuss research gaps namely thermal stability, substrate specificity and residual activity of enzymes that may play a vital role in the selection of enzymes with optimal effectiveness against multi species biofilms. The outcome of this mini review will aid in the development of a novel and sustainable enzyme-based CIP treatment during cheese manufacturing in the future.

Keywords: biofilms, EPS, cheese manufacturing, enzymes, CIP

\section{INTRODUCTION}

In the dairy industry including cheese manufacturing, bacteria colonize processing surfaces through biofilms which may adversely impact the quality and safety of milk and cheese products by contamination (Bremer et al., 2009; Sadiq et al., 2016).

To combat biofilms, the dairy industry uses CIP methods involving circulation of cleaning solutions containing $0.5-2 \%$ caustic soda and $0.5-1 \%$ nitric acid at high velocity with turbulent flow at elevated temperatures (Seale et al., 2010; Thomas and Sathian, 2014). Previous studies have indicated that the effectiveness of CIP treatments can vary in eliminating surface adhered biofilms, raising the need for an alternative treatment with a higher reliability (Faille et al., 2001; Marchand et al., 2012). Bremer et al., 2006, studied the effectiveness of different CIP treatments and reported a large variation in the ability of sodium hydroxide to consistently remove dairy biofilms. This finding was in accordance with previous studies that have reported such variations (Flint et al., 1999; Dufour et al., 2004). Several factors including the age, composition of the biofilm, cleaning time and temperature have been previously identified to influence the effectiveness of CIP treatments (Changani et al., 1997; Lelievre et al., 2001).

Recent advancements have highlighted the role of enzymes in replacing the caustic-based cleaning agents with potential benefits including reduced energy and water consumption, environmental impact and improved safety (Boyce et al., 2010; Delhalle et al., 2020). Previous studies have primarily focused on enzyme-based strategies to combat biofilms in the medical and food industry except cheese manufacturing (Nahar et al., 2018; Saggu et al., 2019; Jiang et al., 2020). In this mini review, we provide an overview on the role of enzymes as an alternative 
CIP treatment and their mechanism of action on biofilms during cheese manufacturing which has not been discussed previously. In addition, we highlight some research gaps in the use of enzymes as a potential CIP agent during cheese manufacturing. This information will benefit future investigations on the underlying mechanism of action of enzymes on biofilms in the dairy industry.

\section{BIOFILM FORMATION IN A CHEESE MANUFACTURING PLANT-THE UNDERLYING PROBLEM}

Johnson et al., 2021, demonstrated variation among microbial sub populations within sections of cheese manufacturing environments. The process flow diagram of cheese manufacturing is shown in Figure 1. Raw milk stored in silos at low temperatures is prone to microbial contamination resulting from the formation of biofilms by heat sensitive Pseudomonas and Listeria species (Shaheen et al., 2010; Marchand et al., 2012). In addition, Zhang et al., 2020, demonstrated that psychotropic bacteria are capable of growing and forming biofilms during storage of refrigerated raw milk. Raw milk can be contaminated with heat stable enzymes produced by a broad spectrum of psychotropic bacteria which may survive heat processing steps and can affect the quality of dairy products including cheese (Vithanage et al., 2016). Following storage in silos, raw milk is pasteurized to reduce the population of planktonic cells including spoilage microorganisms (Visser and Jeurnink, 1997). However, vegetative cells and spores of psychrotrophic, mesophilic and thermophilic bacteria are capable of surviving such treatments, germinating, and forming biofilms within the plate heat exchanger (PHE) (Meer et al., 1991; Flint et al., 2002; Hinton et al., 2002) or on processing equipment (Kumar et al., 2021). Equipment surfaces in the draining and matting conveyor (DMC) are made of stainless steel which is a known substrate for biofilm formation by psychrotrophic, mesophilic and thermophilic bacteria (Suarez et al., 1992; Zhao et al., 2013; Sadiq et al., 2017; Kumar et al., 2021). In addition to stainless steel pipelines, the accumulation of food borne pathogens in the form of biofilms on rubber gaskets and seals made of Buna-N and Teflon have been discussed previously (Austin and Bergeron, 1995; Kumar and Anand, 1998). In the design of an enzyme-based CIP treatment, it is vital to consider the spatial, temporal variability of microbial sub populations at different sections of the cheese manufacturing plant and the varying chemical composition of biofilms which consequently demands an optimized enzyme combination for their removal.

\section{MECHANISM OF ACTION OF ENZYMES ON BIOFILMS}

In bacterial biofilms, the extracellular matrix plays a vital role in the establishment and maintenance of the biofilm structure and is composed primarily of extracellular polymeric substances (EPS) (Flemming and Wingender, 2010; Di Martino, 2018). The
EPS matrix is composed of proteins, polysaccharides, and nucleic acids (eDNA and RNA) along with lipids and ions (Kristensen et al., 2008; Whitfield et al., 2015; Coughlan et al., 2016). Previous studies have identified a strain related variation in the composition of polysaccharides in the EPS matrix (Banik et al., 2007; Torres et al., 2012; Roca et al., 2015; Zhang et al., 2015). In addition to strain variation, several other factors can potentially influence the yield and composition of the EPS matrix (Li et al., 2021). Lequette et al., 2010, analyzed the cleaning efficiency of polysaccharidase and proteolytic enzymes against biofilms of bacterial species isolated from the food industry and concluded that the composition of the EPS matrix affected the choice and cleaning efficiency of the enzyme treatment. In Figure 2, we demonstrate the mechanism of action of an enzyme cocktail containing polysaccharide hydrolase, protease, and DNase on a mature biofilm matrix.

Earlier studies have discussed the effect of alkaline and acidic cleaning agents on the biofilm matrix which differs in comparison with enzymes (Liikanen et al., 2002; Parkar et al., 2004; Dogsa et al., 2005). The substrate specificity of enzymes may contribute toward their enhanced efficiency for the removal of biofilms in comparison with alkali and acid cleaning agents and needs further investigation. In addition, the design of an enzyme-based CIP treatment should proceed in tandem with developing good hygiene practices of equipment, surfaces, and devices.

\section{GAPS AND FUTURE RECOMMENDATIONS}

Studying the potential advantages and shortcomings in the use of enzymes for CIP treatment is important for designing a robust cleaning regime with a higher cleaning efficiency compared to conventional CIP treatments.

Thermal stability of enzymes plays a vital role in determining the enzymatic activity which may impact the efficiency of the CIP treatment (Boyce et al., 2010). These authors demonstrated that three commercial proteases were inactivated by any of the heat sanitation steps commonly employed in the dairy industry. Future research should further investigate the thermal stability of several commercially available enzymes and consider the same when designing an effective CIP treatment. Lequette et al., 2010, who screened the biofilm removal ability of seven proteases and polysaccharidase concluded that the efficiency of enzymes on biofilm removal depended on the bacterial species with proteases being more efficient in removing Bacillus biofilms in contrary to polysaccharidase being more effective against Pseudomonas fluorescens biofilms of industrial origin. To our knowledge, the use of enzymes for CIP does not imply any associated effects on bacterial viability within biofilms. Further research is warranted to study the substrate specificity of enzymes to increase the range of action of an enzyme treatment against multi species who form complex biofilms of varying compositions. Besides the thermal stability and substrate specificity, the residual activity of an enzyme is a critical parameter that may impact the selection criteria for enzymes to be used in CIP treatments. Boyce et al., 2010, concluded that an acid circulation step 


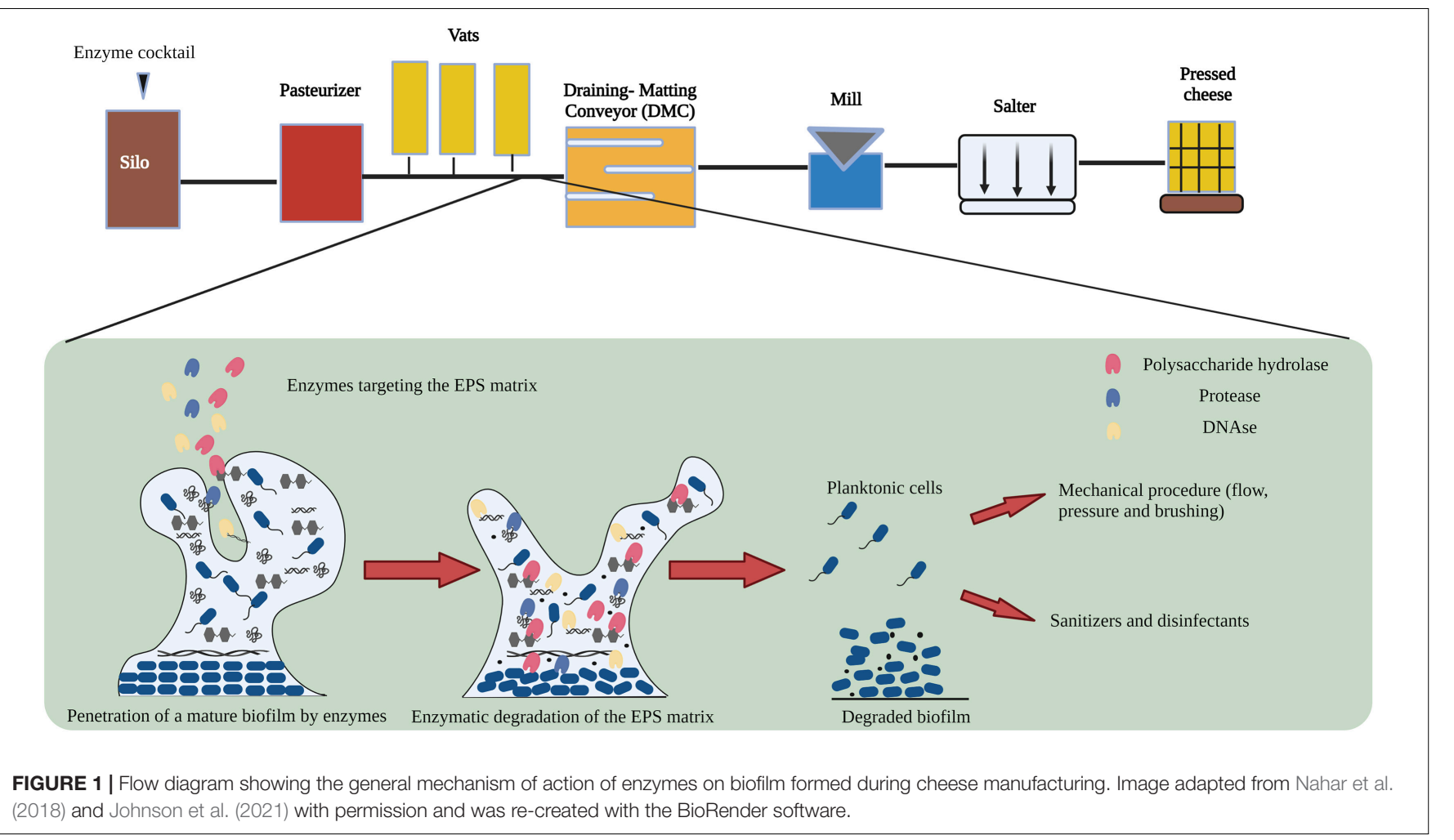

FIGURE 1 | Flow diagram showing the general mechanism of action of enzymes on biofilm formed during cheese manufacturing. Image adapted from Nahar et al. (2018) and Johnson et al. (2021) with permission and was re-created with the BioRender software.

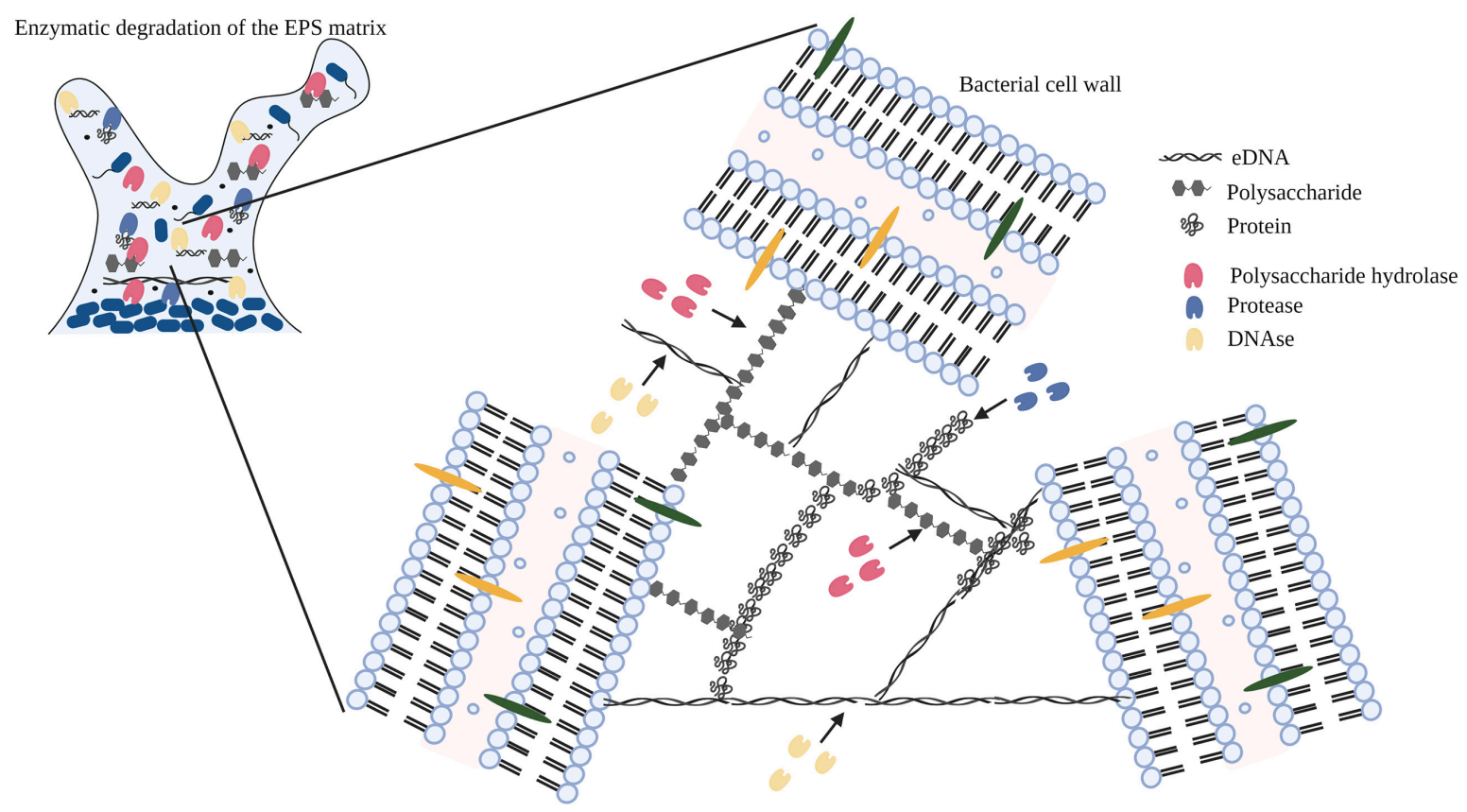

FIGURE 2 | Diagrammatic representation of the mechanism of action of enzymes (polysaccharide hydrolase, protease, and DNase) targeting exopolysaccharides, proteins, and eDNA within the EPS matrix. Image has been adopted from Nahar et al. (2018) with permission and was recreated with BioRender software. Black arrows indicate the binding of the enzyme to the substrate.

$\left(0.5-1 \%\right.$ nitric acid at $\left.60^{\circ} \mathrm{C}\right)$ is capable of inactivating the residual enzyme activity of ten commercial proteases and lipases, remaining on the processing equipment surface after cleaning.
In the cheese industry, residual enzyme activity may impact the quality of cheese through bitterness generation, excessive proteolysis and lipolysis and hence processing steps are needed 
to ensure complete inactivation of any added enzyme used for CIP. Furthermore, the impact of enzymes on the dairy processing wastewater treatment needs to be evaluated and future steps should focus on the recovery of enzymes from dairy processing wastewater sludge (DPS). Future research on the development of an enzyme-based CIP treatment for cheese manufacturing in the European Union must comply with the expectations on the use of enzymes in the food industry as per regulations (EC) No $1332 / 2008$ and (EC) No 648/2004.

In addition to enhanced cleaning efficiency, enzyme-based cleaning is associated with lower rinsing volumes which results in reduced water consumption and water costs (Boyce et al., 2010). Moreover, the wastewater generated from an enzymebased cleaning may require minimal processing due to lack of need for a neutralization step involving the lowering of the $\mathrm{pH}$ of the effluent stream which may also lower the operating cost (D’Souza and Mawson, 2005).

\section{CONCLUSION}

The implementation of an enzyme-based cleaning as an alternative to traditional CIP treatment is favorable due to

\section{REFERENCES}

Austin, J. W., and Bergeron, G. (1995). Development of bacterial biofilms in dairy processing lines. J. Dairy Res. 62, 509-519. doi: 10.1017/S0022029900031204

Banik, R. M., Santhiagu, A., and Upadhyay, S. N. (2007). Optimization of nutrients for gellan gum production by Sphingomonas paucimobilis ATCC-31461 in molasses based medium using response surface methodology. Bioresour. Technol. 98, 792-797. doi: 10.1016/j.biortech.2006.03.012

Boyce, A., Piterina, A. V., and Walsh, G. (2010). Assessment of the potential suitability of selected commercially available enzymes for cleaning-in-place (CIP) in the dairy industry. Biofouling 26, 837-850. doi: 10.1080/08927014. 2010.522705

Bremer, P., Seale, B., Flint, S., and Palmer, J. (2009). "15 - Biofilms in dairy processing," in Biofilms in the Food and Beverage Industries, eds P. M. Fratamico, B. A. Annous, and N. W. Guenther (Amsterdam: Elsevier), 396-431.

Bremer, P. J., Fillery, S., and McQuillan, A. J. (2006). Laboratory scale CleanIn-Place (CIP) studies on the effectiveness of different caustic and acid wash steps on the removal of dairy biofilms. Int. J. Food Microbiol. 106, 254-262. doi: 10.1016/j.ijfoodmicro.2005.07.004

Changani, S. D., Belmar-Beiny, M. T., and Fryer, P. J. (1997). Engineering and chemical factors associated with fouling and cleaning in milk processing. Exp. Therm. Fluid Sci. 14, 392-406. doi: 10.1016/S0894-1777(96)00141-140

Coughlan, L. M., Cotter, P. D., Hill, C., and Alvarez-Ordóñez, A. (2016). New weapons to fight old enemies: novel strategies for the (bio)control of bacterial biofilms in the food industry. Front. Microbiol. 7:1641. doi: 10.3389/fmicb.2016. 01641

Delhalle, L., Taminiau, B., Fastrez, S., Fall, A., Ballesteros, M., Burteau, S., et al. (2020). Evaluation of enzymatic cleaning on food processing installations and food products bacterial microflora. Front. Microbiol. 11:1827. doi: 10.3389/ fmicb.2020.01827

Di Martino, P. (2018). Extracellular polymeric substances, a key element in understanding biofilm phenotype. AIMS Microbiol. 4, 274-288. doi: 10.3934/ microbiol.2018.2.274

Dogsa, I., Kriechbaum, M., Stopar, D., and Laggner, P. (2005). Structure of bacterial extracellular polymeric substances at different $\mathrm{pH}$ values as determined by SAXS. Biophys. J. 89, 2711-2720. doi: 10.1529/biophysj.105.061648

D'Souza, N. M., and Mawson, A. J. (2005). Membrane cleaning in the dairy industry: a review. Crit. Rev. Food Sci. Nutr. 45, 125-134. doi: 10.1080/ 10408690490911783 the improved cleaning performance provided there is no deterioration to the product quality. In this review, we highlight the mechanism of action of enzymes used as a CIP treatment, however, further studies are needed to study the substrate specificity and thermal stability of commercially available enzymes that can be used as cleaning agents in cheese manufacturing.

\section{AUTHOR CONTRIBUTIONS}

MK conducted the literature review and wrote the manuscript. JT and MW edited and revised the manuscript. All authors contributed to the article and approved the submitted version.

\section{FUNDING}

This work was funded by the Department of Agriculture, Fisheries and the Marine (DAFM) (2019R475), under the Food Institutional Research Measure (FIRM).

Dufour, M., Simmonds, R. S., and Bremer, P. J. (2004). Development of a laboratory scale clean-in-place system to test the effectiveness of "natural" antimicrobials against dairy biofilms. J. Food Prot. 67, 1438-1443. doi: 10.4315/0362-028X-67. 7.1438

Faille, C., Fontaine, F., and Bénézech, T. (2001). Potential occurrence of adhering living Bacillus spores in milk product processing lines. J. Appl. Microbiol. 90, 892-900. doi: 10.1046/j.1365-2672.2001.01321.x

Flemming, H. C., and Wingender, J. (2010). The biofilm matrix. Nat. Rev. Microbiol. 8, 623-633. doi: 10.1038/nrmicro2415

Flint, S., Brooks, J., Bremer, P., Walker, K., and Hausman, E. (2002). The resistance to heat of thermo-resistant Streptococci attached to stainless steel in the presence of milk. J. Ind. Microbiol. Biotechnol. 28, 134-136. doi: 10.1038/sj/jim/ 7000229

Flint, S. H., Van Den Elzen, H., Brooks, J. D., and Bremer, P. J. (1999). Removal and inactivation of thermo-resistant Streptococci colonising stainless steel. Int. Dairy J. 9, 429-436. doi: 10.1016/S0958-6946(99)00048-5

Hinton, A. R., Trinh, K. T., Brooks, J. D., and Manderson, G. J. (2002). Thermophile survival in milk fouling and on stainless steel during cleaning. Food Bioproducts Proc. Trans. Instit. Chem. Eng. C 80, 299-304. doi: 10.1205/ 096030802321154817

Jiang, Y., Geng, M., and Bai, L. (2020). Targeting biofilms therapy: current research strategies and development hurdles. Microorganisms 8, 1-34. doi: 10.3390/ microorganisms 8081222

Johnson, J., Curtin, C., and Waite-Cusic, J. (2021). The cheese production facility microbiome exhibits temporal and spatial variability. Front. Microbiol. 12:644828. doi: 10.3389/fmicb.2021.644828

Kristensen, J. B., Meyer, R. L., Laursen, B. S., Shipovskov, S., Besenbacher, F., and Poulsen, C. H. (2008). Antifouling enzymes and the biochemistry of marine settlement. Biotechnol. Adv. 26, 471-481. doi: 10.1016/j.biotechadv.2008.0 5.005

Kumar, C. G., and Anand, S. K. (1998). Significance of microbial biofilms in food industry: a review. Int. J. Food Microbiol. 42, 9-27. doi: 10.1016/S0168-1605(98) 00060-9

Kumar, M., Flint, S., Palmer, J., Chanapha, S., and Hall, C. (2021). Influence of the incubation temperature and total dissolved solids concentration on the biofilm and spore formation of dairy isolates of Geobacillus stearothermophilus. Appl. Environ. Microbiol. 87, 1-10. doi: 10.1128/aem.02311-20

Lelievre, C., Faille, C., and Benezech, T. (2001). Removal kinetics of Bacillus cereus spores from stainless steel pipes under CIP procedure: influence of soiling and 
cleaning conditions. J. Food Process Eng. 24, 359-379. doi: 10.1111/j.1745-4530. 2001.tb00549.x

Lequette, Y., Boels, G., Clarisse, M., and Faille, C. (2010). Using enzymes to remove biofilms of bacterial isolates sampled in the food-industry. Biofouling 26, 421-431. doi: 10.1080/08927011003699535

Li, Y., Xin, M., Xie, D., Fan, S., Ma, J., Liu, K., et al. (2021). Variation in extracellular polymeric substances from Enterobacter sp. and their $\mathrm{Pb} 2+$ adsorption behaviors. ACS Omega 6, 9617-9628. doi: 10.1021/acsomega.1c00185

Liikanen, R., Yli-Kuivila, J., and Laukkanen, R. (2002). Efficiency of various chemical cleanings for nanofiltration membrane fouled by conventionallytreated surface water. J. Membr. Sci. 195, 265-276. doi: 10.1016/S0376-7388(01) 00569-5

Marchand, S., De Block, J., De Jonghe, V., Coorevits, A., Heyndrickx, M., and Herman, L. (2012). Biofilm formation in milk production and processing environments; influence on milk quality and safety. Compr. Rev. Food Sci. Food Saf. 11, 133-147. doi: 10.1111/j.1541-4337.2011.00183.x

Meer, R. R., Baker, J., Bodyfelt, F. W., and Griffiths, M. W. (1991). Psychrotrophic Bacillus spp. in fluid milk products: a review. J. Food Protect. 54, 969-979.

Nahar, S., Mizan, M. F. R., Ha, A. J. W., and Ha, S. D. (2018). Advances and future prospects of enzyme-based biofilm prevention approaches in the food industry. Compr. Rev. Food Sci. Food Saf. 17, 1484-1502. doi: 10.1111/1541-4337. 12382

Parkar, S. G., Flint, S. H., and Brooks, J. D. (2004). Evaluation of the effect of cleaning regimes on biofilms of thermophilic bacilli on stainless steel. J. Appl. Microbiol. 96, 110-116. doi: 10.1046/j.1365-2672.2003.02136.x

Roca, C., Alves, V. D., Freitas, F., and Reis, M. A. M. (2015). Exopolysaccharides enriched in rare sugars: bacterial sources, production, and applications. Front. Microbiol. 6:288. doi: 10.3389/fmicb.2015.00288

Sadiq, F. A., Flint, S., Yuan, L., Li, Y., Liu, T. J., and He, G. Q. (2017). Propensity for biofilm formation by aerobic mesophilic and thermophilic spore forming bacteria isolated from Chinese milk powders. Int. J. Food Microbiol. 262, 89-98. doi: 10.1016/j.ijfoodmicro.2017.09.015

Sadiq, F. A., Li, Y., Liu, T. J., Flint, S., Zhang, G., Yuan, L., et al. (2016). The heat resistance and spoilage potential of aerobic mesophilic and thermophilic spore forming bacteria isolated from Chinese milk powders. Int. J. Food Microbiol. 238, 193-201. doi: 10.1016/j.ijfoodmicro.2016.09.009

Saggu, S. K., Jha, G., and Mishra, P. C. (2019). Enzymatic degradation of biofilm by metalloprotease from Microbacterium sp. Sks10. Front. Bioeng. Biotechnol. 7:192. doi: 10.3389/fbioe.2019.00192

Seale, R. B., Bremer, P. J., Flint, S. H., and McQuillan, A. J. (2010). Characterization of spore surfaces from a Geobacillus sp. isolate by $\mathrm{pH}$ dependence of surface charge and infrared spectra. J. Appl. Microbiol. 109, 1339-1348. doi: 10.1111/j. 1365-2672.2010.04760.x

Shaheen, R., Svensson, B., Andersson, M. A., Christiansson, A., and SalkinojaSalonen, M. (2010). Persistence strategies of Bacillus cereus spores isolated from dairy silo tanks. Food Microbiol. 27, 347-355. doi: 10.1016/j.fm.2009.11.004

Suarez, B., Ferreiros, C. M., and Criado, M. T. (1992). Adherence of psychrotrophic bacteria to dairy equipment surfaces. J. Dairy Res. 59, 381-388. doi: 10.1017/ S002202990003065X
Thomas, A., and Sathian, C. T. (2014). Cleaning-in-place (CIP) system in dairy plant- review. IOSR J. Environ. Sci. Toxicol. Food Technol. 8, 41-44. doi: 10 9790/2402-08634144

Torres, C. A. V., Antunes, S., Ricardo, A. R., Grandfils, C., Alves, V. D., Freitas, F., et al. (2012). Study of the interactive effect of temperature and $\mathrm{pH}$ on exopolysaccharide production by Enterobacter A47 using multivariate statistical analysis. Bioresour. Technol. 119, 148-156. doi: 10.1016/j.biortech. 2012.05.106

Visser, J., and Jeurnink, T. J. M. (1997). Fouling of heat exchangers in the dairy industry. Exp. Therm. Fluid Sci. 14, 407-424. doi: 10.1016/S0894-1777(96) 00142-2

Vithanage, N. R., Dissanayake, M., Bolge, G., Palombo, E. A., Yeager, T. R., and Datta, N. (2016). Biodiversity of culturable psychrotrophic microbiota in raw milk attributable to refrigeration conditions, seasonality and their spoilage potential. Int. Dairy J. 57, 80-90. doi: 10.1016/j.idairyj.2016.02.042

Whitfield, G. B., Marmont, L. S., and Howell, P. L. (2015). Enzymatic modifications of exopolysaccharides enhance bacterial persistence. Front. Microbiol. 6:471. doi: $10.3389 /$ fmicb.2015.00471

Zhang, D., Palmer, J., Teh, K. H., and Flint, S. (2020). Identification and selection of heat-stable protease and lipase-producing psychrotrophic bacteria from fresh and chilled raw milk during up to five days storage. Lwt 134:110165. doi: 10.1016/j.lwt.2020.110165

Zhang, J., Dong, Y. C., Fan, L. L., Jiao, Z. H., and Chen, Q. H. (2015). Optimization of culture medium compositions for gellan gum production by a halobacterium Sphingomonas paucimobilis. Carbohydr. Polym. 115, 694-700. doi: 10.1016/j. carbpol.2014.09.029

Zhao, Y., Caspers, M. P. M., Metselaar, K. I., De Boer, P., Roeselers, G., Moezelaar, R., et al. (2013). Abiotic and microbiotic factors controlling biofilm formation by thermophilic sporeformers. Appl. Environ. Microbiol. 79, 5652-5660. doi: 10.1128/AEM.00949-13

Conflict of Interest: JT is employed by Glanbia Ingredients, Ireland.

The remaining authors declare that the research was conducted in the absence of any commercial or financial relationships that could be construed as a potential conflict of interest.

Publisher's Note: All claims expressed in this article are solely those of the authors and do not necessarily represent those of their affiliated organizations, or those of the publisher, the editors and the reviewers. Any product that may be evaluated in this article, or claim that may be made by its manufacturer, is not guaranteed or endorsed by the publisher.

Copyright (c) 2021 Kumar, Tierney and Wilkinson. This is an open-access article distributed under the terms of the Creative Commons Attribution License (CC BY). The use, distribution or reproduction in other forums is permitted, provided the original author(s) and the copyright owner(s) are credited and that the original publication in this journal is cited, in accordance with accepted academic practice. No use, distribution or reproduction is permitted which does not comply with these terms. 